\title{
KEARIFAN LOKAL DALAM PENGELOLAAN HUTAN (STUDI KASUS KELEMBAGAAN SASI HUTAN DI DESA KAILOLO KECAMATAN PULAU HARUKU KABUPATEN MALUKU TENGAH)
}

\author{
LOCAL FUNCTIONS IN FOREST MANAGEMENT \\ (CASE STUDY OF FOREST INSTITUTION IN KAILOLO VILLAGE KECAMATAN PULAU \\ HARUKU CENTRAL MALUKU DISTRICT
}

\author{
Husain Marasabessy \\ Jurusan Kehutanan Fakultas Pertanian Universitas Pattimura Ambon \\ Jl. Ir. M. Putuhena. Kampus Poka Ambon 97237 \\ Penulis Korespondensi Email : husain.marasabessy@faperta.unpatti.ac.id
} \begin{tabular}{|l|l|}
\hline Diterima : 5 Oktober 2017 & Disetujui : 28 November 2017
\end{tabular}

\section{Intisari}

Penelitian ini bertujuan untuk mengetahui peranan kelembagaan lokal sasi dalam kegiatan pengelolaan hutan, yang dapat dijadikan dalam merumuskan bentuk pengelolaan hutan berdasarkan karateristik wilayah dalam mewujudkan pengelolaan hutan secara lestari serta peningkatan kesejahteraan masyarakat. Pengumpulan data dilakukan dengan cara observasi terhadap semua aktivitas masyarakat baik dalam hutan maupun di wilayah pemukiman. Wawancara dilakukan dengan semua stakeholder untuk memperoleh data dan informasi secara sistematis dan intensif diantaranya pemerintah desa, pengelola (kewang), tokoh-tokoh pemuda dan pelajar, instansi terkait, akademisi, LSM dan studi dokumentasi berupa studi kepustakaan dan foto-foto yang berkaitan dengan penelitia. Hasil penelitian menunjukan bahwa sasi merupakan suatu bentuk larangan sementara kepada masyarakat untuk menahan diri dalam mengeksploitasi semberdaya alam yang berada di darat yang dimiliki secara pribadi (non ulayat) maupun secara bersama (hak ulayat) dan dilaut yang dimiliki oleh lembaga pengelola (Kewang). Hukum sasi untuk wilayah darat (hutan) memiliki tahapan pengelolaan yaitu perencanaan, pelaksanaan, pengawasan, pengelolaan hasil, dan pemasaran. Kebijakan-kebijakan pemerintah diidang kehutanan seperti UU nomor 41 tahun 1999 tentang kehutanan dan keputusan menteri kehutanan nomor 31 tahun 2001 tentang hukum kemasyarakatan dilihat masih sejalan dengan hukum sasi. Dalam perkembangannya, sasi sebagai model kearifan lokal masyarakat di Provinsi Maluku menghadapi hambatan dalam pelaksanaannya, baik yang datang dari luar maupun dari dalam masyarakat, seperti tidak sebandingnya luas wilayah hutan dengan jumlah anggota kewang, benturan antara hukum adat dengan hukum nasional dan kebijakan pemerintah berupa HPH yang merupakan ancaman terhadap wilayah petuanan negeri.

Kata Kunci : Sasi , Kearifan Lokal, Sumberdaya Hutan

\begin{abstract}
This study aims to determine the role of local Sasi institutions in forest management activities, which can be used in formulating forms of forest management based on regional characteristics in realizing sustainable forest management and improving community welfare. Data collection is done by observing all community activities both in the forest and in residential areas. Interviews are conducted with all stakeholders to obtain systematic and intensive data and information including village government, managers (kewang), youth and student leaders, academics, NGOs and documentation studies in the form of library studies and photographs relating to research.

The results of the study show that sasi is a form of temporary prohibition on the community to refrain from exploiting natural resources that are on land that are privately owned (non-communal) or collectively (communal rights) and at sea owned by the management agency (Kewang). Sasi law for teresterial land (forest) has management stages, namely planning, implementation, supervision, yield management, and marketing. Government policies in the forestry sector such as the forestry law number 41 of 1999 year concerning forestry, and the decision of the minister of forestry number 31 of 2001 year concerning social law are seen to be in line with the sasi law. In its development, sasi as a model of local wisdom in Moluccas Province faced obstacles in its implementation, both those who
\end{abstract}


came from outside and inside the community, such as the proportion of forest area with the number of members of the community, conflicts between customary law and national law, and government policies in the form of HPH which is a threat to the territory of the country..

Keywords: Sasi, Local Wisdom, Forest Resources

\section{PENDAHULUAN}

Hutan merupakan modal pembangunan nasional dan daerah, yang memiliki manfaat baik manfaat ekologi, sosial, maupun ekonomi secara seimbang dan dinamis. Luas hutan berdasarkan fungsinya di Provinsi Maluku seluas 4.124.362 ha, terdiri atas hutan lindung seluas 839.970 ha, hutan produksi tetap seluas 576.975 ha, hutan produksi teratas seluas 952.852 ha, hutan wisata seluas 404.948 ha, dan hutan konvensi seluas 1.349.607 ha. Sistem pengelolaan hutan selama orde baru diambil-alih oleh pemerintah, dengan memberikan wewenang kepada HPH seluas 3.061.198 ha. Selain itu diluar kawasan hutan, pengelolaan sumberdaya alam dilakukan oleh masyarakat lokal dengan sistem hutan rakyat sebagai sumber kehidupan masyarakat setempat.

Pengelolaan hutan adalah ilmu atau penggunaan praktis aspek ilmiah dan teknis kehutanan dengan memperhitungkan prinsip - prinsip ekonomi dan sosial dalam pengurusan, pengelolaan, administrasi dan pengaturan sumberdaya hutan untuk mencapai tujuan dan beberapa tujuan tertentu. Pengelolaan sumberdaya alam dan lingkungan hidup didasarkan pada ketentuan-ketentuan hukum yang dapat melindungi sumberdaya alam, dan aktivitas

manusia yang dapat berpotensi terhadap kerusakan lingkungan. Ketentuan-ketentuan yang dimaksud antara lain kelembagaan sasi, yang bertujuan melindungi sumberdaya alam pada daerah - daerah tertentu dari berbagai aktivitas warga masyarakat. kelembagaan sasi dapat berperan sebagai landasan dalam upaya untuk mengamankan hak petuanan dari persekutuan masyarakat baik didarat maupun dilaut.

Kelembagaan adalah sekumpulan aturan main, prosedur, norma dan etika berperilaku yang dirancang dan disepakati untuk membatasi tingkah laku individu. Kelembagaan kewang di setiap daerah berbeda-beda, dan berfungsi untuk melindungi sumberdaya alam dari aktivitas warga masyarakat yang tidak bertanggung jawab. Kelembagaan ini berjalan secara bersamaan dengan sasi sampai saat ini. Sasi dan kewang merupakan wujud kearifan masyarakat di Provinsi Maluku, yang sudah membudaya daerah - daerah.

Sasi adalah ketentuan-ketentuan hukum tentang larangan memasuki, mengambil atau melakukan sesuatu dalam suatu kawasan tertentu dan dalam jangka waktu yang tertentu pula. Sasi hutan adalah sasi yang mengatur kegiatan eksploitasi 
(pemungutan) semua sumberdaya didarat (hutan). Kearifan masyarakat terwujud atas kesadaran partisipasi masyarakat dalam melestarikan sumberdaya alam baik didarat maupun di laut. Dalam hal ini, sasi merupakan model kesadaran dan partisipasi masyarakat yang berguna dalam mewujudkan pembangunan yang

\section{METODE PENELITIAN}

\section{Lokasi dan Waktu Penelitian}

Penelitian ini dilaksankan di Desa Kailolo Kecamatan Pulau Haruku

\section{Metode Pengumpulan Data}

Dalam penelitian ini pengumpulan data dilakukan dengan cara :

1. Observasi

Dalam kegiatan ini dilakukan pengamatan terhadap berbagai kegiatan dan keadaan didaerah penelitian baik dilingkungan desa maupun dikawasan hutan

2. Wawancara berwawasan lingkungan. Penelitian ini adalah untuk mengetahui peranan kelembagaan lokal sasi dalam kegiatan pengelolaan hutan. Kegunaan diadakan penelitian ini adalah sebagai bahan informasi semua pihak dalam perumusan bentuk pengelolaan hutan secara lestari serta peningkatan kesejahteraan masyarakat.

Kabupaten Maluku Tengah Provinsi Maluku selama dua bulan sejak bulan Nopember 2007 sampai dengan bulan Desember 2007.

Wawancara dilakukan dengan semua stakeholder untuk mengumpulkan data dan informasi dan intensif. Stakeholder yang diwawancarai adalah : pemerintah negeri/desa, pengelola (kewang), tokohtokoh pemuda dan pelajar, istansi terkait, lembaga swadaya masyarakat (LSM), dan pihak akademisi. Perincian responden dapat dilihat pada tabel dibawah ini :

Tabel 1. Rincian Dan Jumlah Responden Serta Informasi Yang Diperoleh

\begin{tabular}{clcl}
\hline No & Jenis Responden & Jumlah & \multicolumn{1}{c}{ Jenis Informasi Yang Diperoleh } \\
\hline 1. & Pemerintah Desa & 10 & Sistem Pelaksana Sasi \\
2. & Pengelola (Kewang) & 4 & Pelaksan Sasi di Lapangan \\
3. & Pemuda dan Pelajar & 5 & Tanggapan Terhadap Sasi \\
4. & Istansi Terkait & 5 & Tanggapan Terhadap Sasi \\
5. & Akademisi & 2 & Tanggapan Terhadap Sasi \\
6. & LSM & 4 & Tanggapan Terhadap Sasi \\
\hline
\end{tabular}

Sumber : Data Primer Setelah di Olah, 2007

3. Studi Dokumentasi
Selain dua cara diatas juga digunakan studi dokumentasi berupa studi kepustakaan 
(literature) dan foto-foto yang berkaitan

dengan penelitian ini

Berdasarkan jenis data yang dikumpulkan, maka data tersebut dapat dibedakan menjadi dua yaitu :

1. Data Primer

Data primer diperoleh melalui wawancara denga stakeholder. Aspek - aspek yang diwawancara meliputi lembaga penyelenggara sasi, tugas dan fungsi lembaga penyelenggara, hubungan kelembagaan (sasi) dengan adat istiadat setempat, hubungan kelembagaan sasi dengan pemerintah, dan ruang lingkup kelembagaan dalam pengelolaan hutan.

\section{HASIL DAN PEMBAHASAN}

\section{A. Deskripsi Sasi}

Sasi secara umum diartikan sebagai pranata tradisional yang mengatur tentang larangan dan kebolehan warga masyarakat dalam mengelola sumberdaya alam serta lingkungan hidup sekitarnya. Sasi juga diartikan sebagai rangakaian pengelolaan hutan atau pemanfaatan hutan dengan selalu berpegang kepada hukum adat/istiadat kebiasaan. Deskripsi mengenai kegiatan sasi adalah sebagai berikut :

1. Wilayah

Pembahasan mengenai wilayah sasi di Maluku tidak bisa terlepas dari adanya konsep kepemilikian, baik kepemilikan bersama (hak ulayat) maupun kepemilikan pribadi (non ulayat). Daerah-daerah di Maluku pada umumnya dan Pulau Haruku pada khususnya
2. Data Sekunder

Data sekunder merupakan data yang diperoleh dari berbagai istansi dan lembaga - lembaga tertentu yang berkaitan dengan penelitian ini. Data sekunder yang dikumpulkan meliputi data potensi daerah dan keadaan umum lokasi.

\section{Analisis Data}

Data primer dan data sekunder yang telah terkumpul dalam penelitian ini akan diolah dan ditabulasi serta diklasifikasikan sesuai dengan tujuan penelitian. Selanjutnya dianalisis secara kualitatif dan kuantitatif untuk mendeskripsikan peranan kelembagaan sasi dalam pengelolaan hutan.

terdapat konsep kepemilikan atas wilayah di darat maupun di laut, yang disebut dengan petuanan.

Wilayah darat yang menjadi kepemilikan penduduk disebut petuanan darat, petuanan darat ini diusahakan oleh seseorang yang kepemilikannya berada ditangan perorangan (non ulayat) ataupun sekelompok orang yang merupakan anggota keluarga besar atau marga yang mempunyai hak yang sama atas suatu wilayah (hak ulayat). Wilayah wilayah petuanan darat yang diusahakan baik milik perorangan maupun milik bersama disebut Dusun, yang semuanya terkena hukum sasi, berdasarkan kesepakatan seluruh masyarakat seluruh negeri (desa), yang disepakati pada saat rapat saniri dapat dilihat pada Gambar 1. 


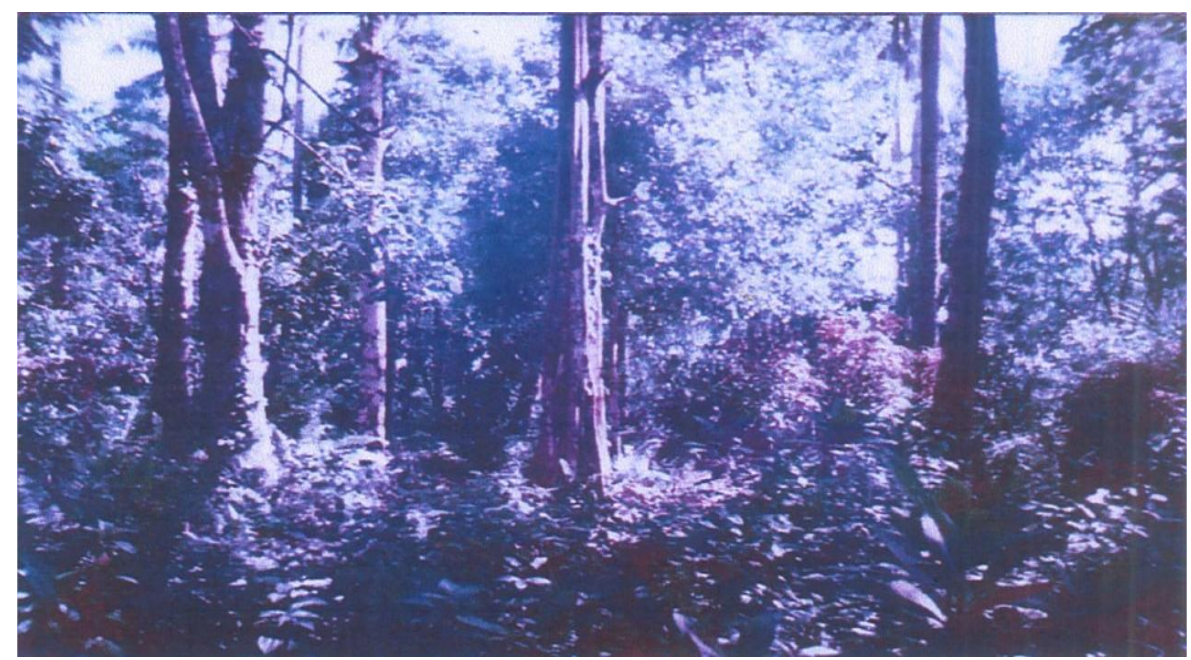

Gambar 1. Wilayah Petuanan Darat (Dusun)

Lain halnya dengan petuanan darat yang kepemilikannya berada ditangan perorangan atau sekelompok orang (marga), maka petuanan laut ini sepenuhnya menjadi milik desa, sehingga apabila petuanan laut ini ingin dikenakan sasi harus mendapatkan persetujuan kepala desa yang bertindak atas nama desa. Sasi (petuanan laut) disajikan pada Gambar 2.

Di Maluku pada umumnya dan dapat ditetapkan apabila memiliki syarat syarat sebagai berikut :

a. Merupakan petuanan negeri

b. Mempunyai batas - batas yang jelas

c. Ketergantungan masyarakat sangat besar pada wilayah tersebut

d. Memiliki sumberdaya yang beraneka ragam dan potensi banyak

e. Mudah dijangkau oleh masyarakat

Maluku Tengah pada khususnya wilayah sasi

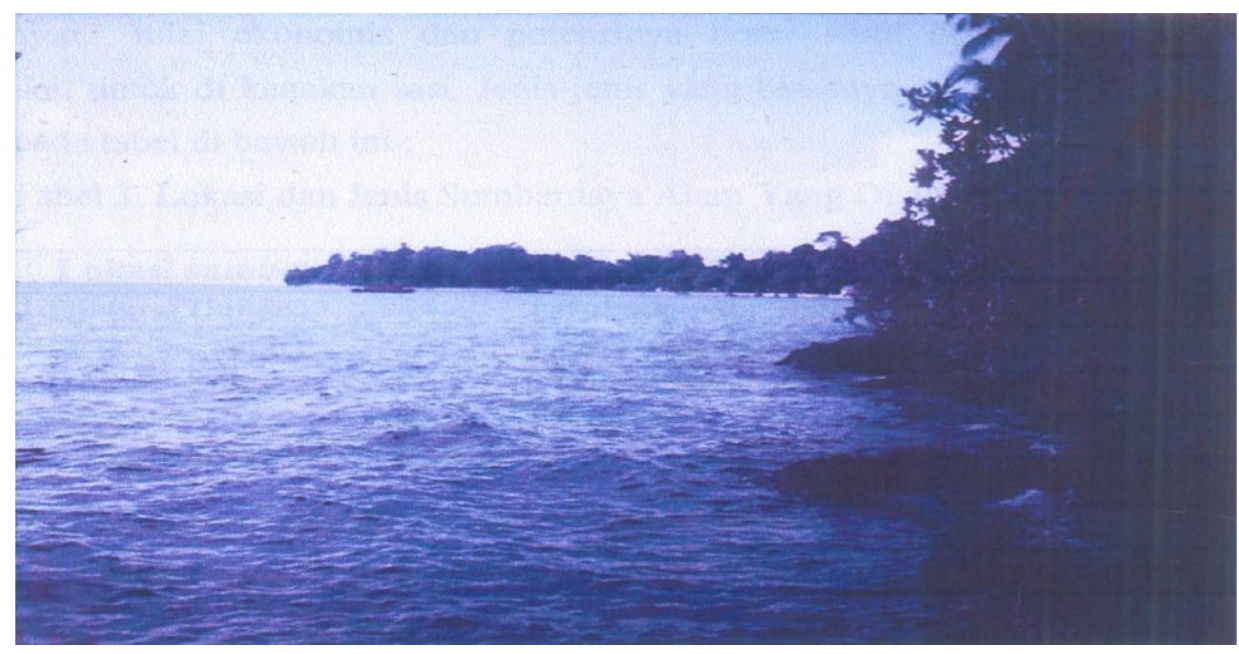

Gambar 2.Wilayah Petuanan Laut (Labuhan) 
Berbicara mengenai wilayah maka didalamnya mengandung arti adanya batas-batas tertentu.

Di Pulau Haruku wilayah petuanan darat maupun wilayah petuanan laut mempunyai batas-batas yang jelas. Hal ini dapat dilihat pada Tabel 2.

Tabel 2. Batas-batas wilayah petuanan Darat dan Wilayah Petuanan Laut

\begin{tabular}{lll}
\hline No & Wilayah Petuanan & Tanda batas \\
\hline 1. & Darat & - Batas alam : Sungai, bukit, tanjung, gua dll. \\
& & - Batas buatan : Pohon yang ditanam, patok dll. \\
2. Laut & - Meti, perairan dangkal, batas desa (garis imajiner). \\
\hline
\end{tabular}

Sumber : Data Primer Setelah di Olah, 2007

Dari Tabel 2 dapat dilihat adanya batas yang jelas untuk wilayah petuanan darat maupun wilayah petuanan laut. Hal ini terlihat adanya kesadaran masyarakat tentang hak masingmasing, baik antara sesama masyarakat maupun antara masyarakat satu desa dengan masyarakat desa lainnya. Selain itu dengan adanya batas-batas tersebut menyebabkan wilayahnya menjadi eksklusif, dalam arti bahwa pengelolaan sumberdaya alam dan lingkungan menjadi hak masyarakat desa yang mengklaimnya.Dengan demikian masyarakat lain dilarang mengeksploitasi sumberdaya yang ada di dalamnya.

\section{Kelembagaan Sasi}

Sebagai pelindung sumberdaya alam hayati, sasi merupakan pranata adat/lembaga adat yang ada di Maluku terutama Maluku Tengah (pulau Haruku) sejak zaman dahulu kala namun demikian tidak jelas sejak kapan sasi itu mulai dikenal karena data dan informasi yang autentik tentang hal tersebut tidak ditemukan. Tetapi berdasarkan cerita masyarakat stempat diperkirakan sejak tahun 1600-an sasi suda mulai dibudayakan dipulau haruku, dengan tujuan untuk melindungi sumberdaya alam hayati dalam desa, menjaga dan memelihara lingkungan hidup, serta melindungi kelestarian dan kerusakan karena ulah manusia.

Sasi berlaku pada semua orang baik orang dalam negeri (anak negeri) maupun orang luar negeri lain untuk itu diletakan tanda larangan agar orang dapat mengetahui sedang tutup sasi. Sasi ditandai dengan berbagai tanda yang sudah dikenal oleh masyarakat, tandatanda sasi dipajang ditempat-tempat yang banyak dilalui orang agar mudah dilihat dan dapat dipatuhi.

Sesuai dengan apa yang dijelaskan sebelumnya bahwa sasi merupakan suatu larangan pengelolaan sumberdaya alam jangka waktu tertentu dimana hukum sasi yang diberlakukan tidak meliputi semua sumberdaya alam, hanya jenis-jenis yang mempunyai nilai ekonomis dan potensinya besar serta disepakati oleh seluruh masyarakat untuk dikenakan sasi. Jenis-jenis yang 
biasanya terkena hukum sasi dapat dilihat pada

tabel dibawah ini :

Tabel 3. Lokasi dan Jenis Sumberdaya Alam yang Dikenai Hukum Sasi

\begin{tabular}{cll}
\hline No & Lokasi Sumberdaya Alam & \multicolumn{1}{c}{ Jenis Sumberdaya Alam } \\
\hline 1. & Didarat (hutan) & Kelapa, pala, durian, cengkih, sagu, dll. \\
2. & Disungai (kali) & Ikan, udang, batu kerikil, pasir, dll \\
3. & Ditepi pantai & Pohon bakau, telur burung maleo, dll. \\
4. & Dilaut & Ikan, lola, teripang, batu karang, pasir, dll. \\
\hline
\end{tabular}

Sumber : Data Primer Setelah di Olah, 2007

Dari hasil pengamatan dan wawancara

masyarakat tidak berminat untuk menawar dilapangan dapat diketahui bahwa jenis sasi maka pemerintah desa berhak untuk yang dilaksanakan didesa kailolo adalah sasi yang didasarkan pada peningkatan mengambil alih kegiatan pengelolaan.

Hak-hak peserta pelelangan adalah kesejahteraan anak negeri berupa sasi babaliang (pembelian). Jenis sasi ini banyak ditemukan didaerah Maluku tengah namun pelaksanaanya berbeda-beda pada satu negeri/desa dengan desa lainnya. Tetapi umumnya dilakukan dengan cara pelelangan (lelang) dan penawar tertinggi berstatus sebagai pembeli dan langsung menjadi pengelola (kewang).

Pelelangan merupakan penjualan yang diadakan terhadap wilayah hutan negeri kepada seluruh masyarakat desa yang dihadiri oleh pemerintah desa, tokoh-tokoh agama, tokoh-tokoh pemuda, pelajar dan masyarakat desa kailolo.Kegiatan ini dimaksudkan untuk memberikan kesempatan kepada seluruh masyarakat yang berminat dalam pengelolaan hutan.Dimana penawar tertinggi akan bertindak sebagai pengelola, pengelolaan bukan saja difokuskan terhadap hasil hutan yang terkena sasi, tetapi juga terhadap seluruh sumberdaya hutan yang harus dijaga dan diamankan dan berbagai tindakan kerusakan agar keberadaanya tetap lestari. Dan apabila 


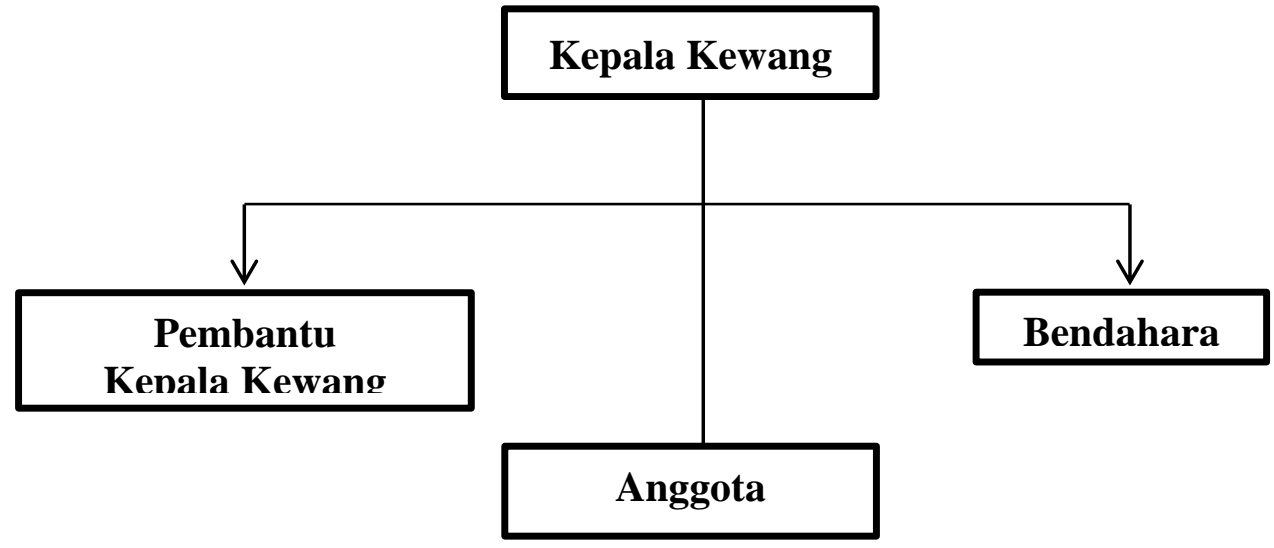

Gambar 3. Struktur Organisasi Lembaga Kewang

Berdasarkan struktur diatas dapat mengetahui susunan dari lembaga kewang didesa kailolo yang terdiri atas kepala kewang, pembantu kepala kewang, bendahara, dan anggota-anggota kewang. Dimana kepala kewang akan bertindak sebagai pimpinan dalam jangka waktu tertentu. Kepala kewang akan mengangkat para pembantunya yaitu seorang pembantu kepala kewang untuk membantu kepala kewang dalam melakukan pengelolaan seluruh sumberdaya alam yang terkena hukum sasi, untuk mengatur masalah keuangan maka kepala kewang mengangkat seorang bendahara untuk mengatur arus keuangan yang berkaitan dengan pengelolaan sumberdaya alam tersebut, selain itu kepala kewang mempunyai beberapa anggota kewang yang membantunya dalam melakukan penjagaan terhadap semua sumberdaya yang dikenai hukum sasi. Anggota-anggota ini dipilih langsung oleh kepala kewang yang jumlahnya disesuaikan dengan luas wilayah yang terkena hukum sasi.

Syarat-syarat anggota kewang adalah sebagai berikut :

1. Merupakan penduduk asli

2. Pekerjannya sebagai petani

3. Mengetahui batas-batas desa dan batas-batas hutan dengan jelas

4. Beribawa, disiplin, tegas, jujur, dan mempunyai kharisma

Jumlah seluruh pengelola (kewang) didesa kailolo berjumlah 14 orang dengan perinciannya : 1 orang kepala kewang, 1 orang pembantu kepala kewang, 1 orang bendahara dan 11 anggota kewang. Tugas dan kewajiban kewang adalah sebagai berikut :

1. Mengamnkan pelaksanaan semua kegiatan sasi yang telah diputuskan pada saat musyawarah (pelelangan).

2. Melaksanakan pemberian sanksi atau hukum kepada warga yang melanggar

3. Memeriksa batas-batas tanah, hutan dan laut yang termasuk dalam wilayah sasi 
4. Memasang atau menancapkan tanda-tanda sasi

Tugas sehari-hari anggota kewang adalah melakukan pengawasan diwilayah petuanan darat maupun laut dan juga

diwilayah pemukiman. Jika terjadi pelanggaran sasi maka anggota kewang berkewajiban melapor kepada kepala kewang, yang bersangkutan akan dihadirkan dihadapan seluruh pengelola (kewang) untuk dimintai keterangan dan selanjutnya diberikan hukuman sesuai dengan kesepakatan seluruh anggota masyarakat. Salah satu contoh tugas anggota kewang dalam melakukan pengawasan didalam hutan (pos jaga) dapat dilihat pada gambar dibawah ini

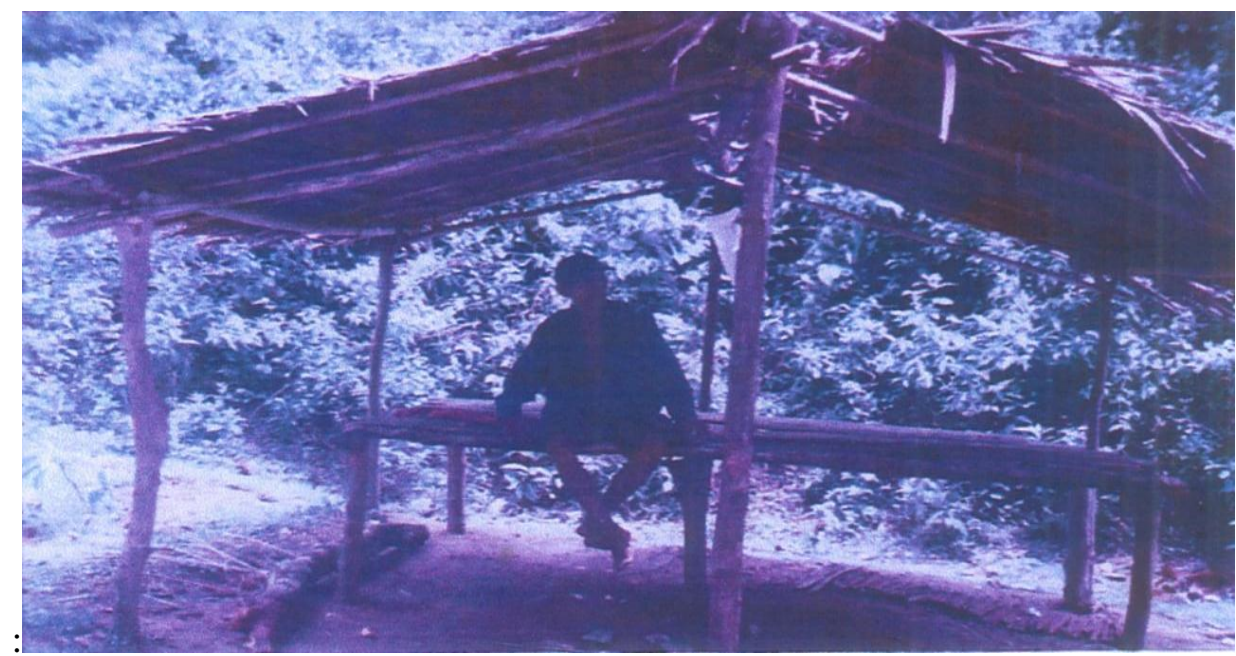

Gambar 4. Salah Satu Anggota Kewang Yang Sedang Melakukan Penjagaan di Pos Jaga

Karena kearifan lembaga kewang melakukan tugasnya maka dalam rangka melindungi kelestarian sumberdaya alam dan lingkungan maka pemerintah RI pada tahun 1985 pernah memberikan hadiah kalpataru kepada kewang pulau Haruku (negeri haruku)kabupaten Maluku tengah yang telah mengelola sumberdaya alam dan lingkungannya.

\section{B. Peranan Sasi Dalam Pengelolaan Hutan}

Sebagaimana telah dibahas sebelumnya bahwa salah satu wilayah yang terkena hukum sasi adalah wilayah darat (hutan) baik yang dimiliki secara perorangan maupun dimiliki bersama.Sasi hutan merupakan sasi yang mengatur seluruh kegiatan eksploitasi (pemungutan) semua sumberdaya didarat (hutan). Deskripsi mengenai sasi hutan adalah sebagai berikut :

\section{Perencanaan}

Pelelangan merupakan tahap awal dimulainya kegiatan sasi hutan, dimana penawar tertingi akan memenangkan pelelangan dan membentuk lembaga pengelola (kewang). Lembaga ini akan bekerja sesuai dengan kesepakatan bersama yang ditetapkan pada saat kegiatan pelelangan selesai. 


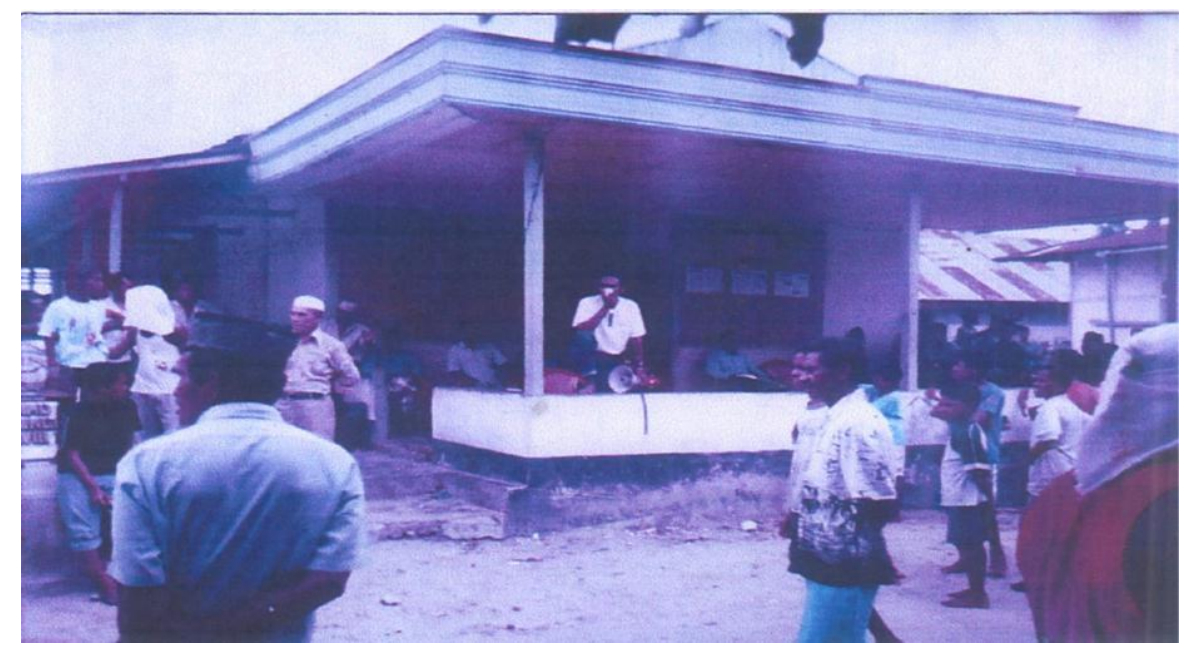

Gambar 5. Suasana Pada Saat Pelelangan di Desa Kailolo

Hal-hal yang disepakati pada saat pelelangan adalah sebagai berikut :

a. Wilayah/lokasi sasi hutan

Wilayah sasi disepakati secara bersama yaitu pada seluruh wilayah petuanan negeri (diluar kawasan hutan) sesuai dengan batas-batas yang telah ditentukan baik diwilayah petuanan yang dimiliki bersama (hak ulayat) maupun wilayah petuanan milik perorangan (non ulayat). Wilayah yang terkena sasi disebut lalean dan hitapori

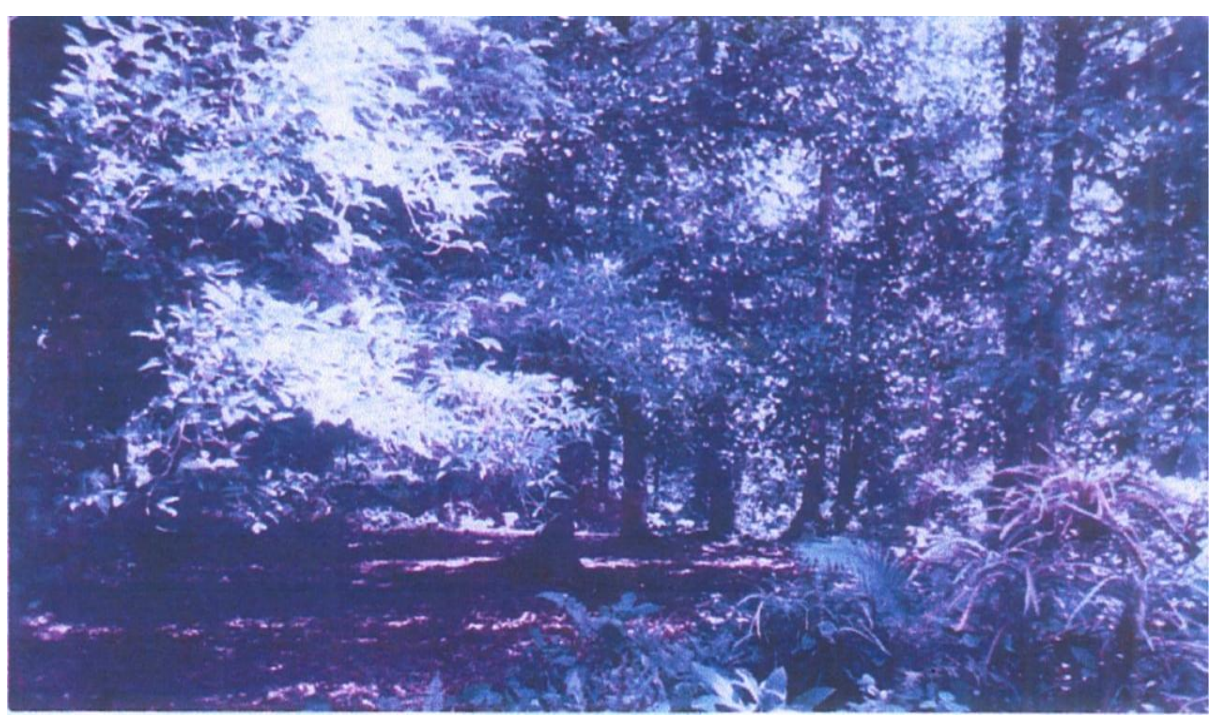

Gambar 6. Salah Satu Wilayah Sasi Hutan (Lalean) 


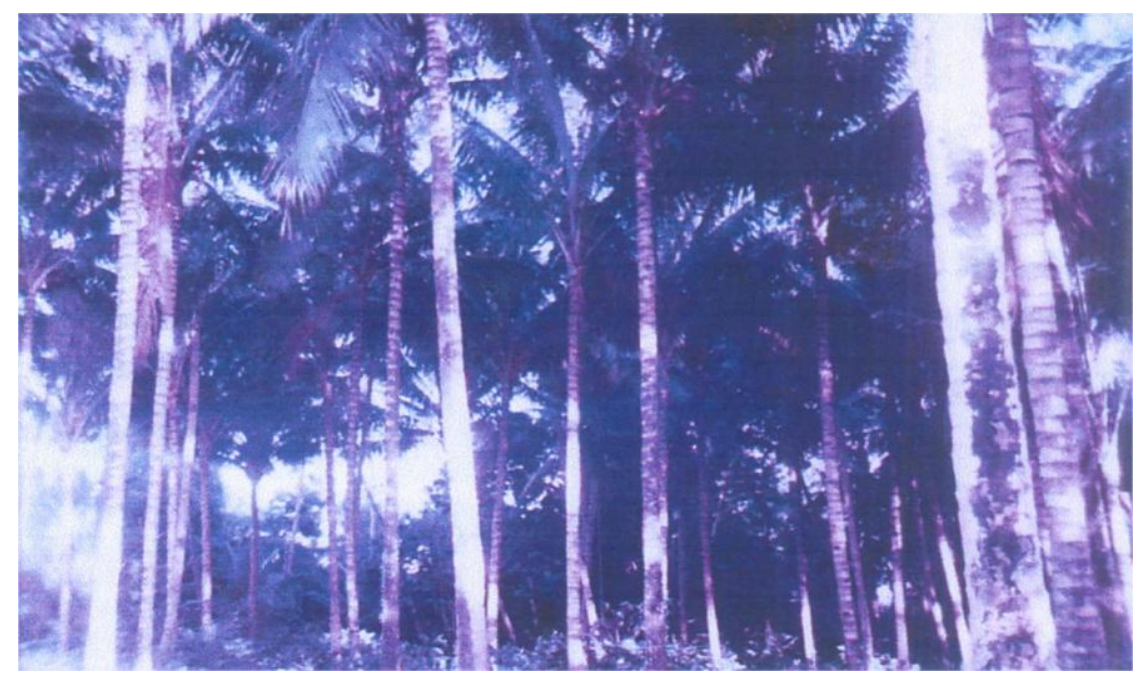

Gambar 7.Salah Satu Wilayah Sasi Hutan (Hitapory)

b. Masa berlaku sasi

Sebelum kegiatan lelang dimulai masa berlaku sasi hutan ditetapkan ditempat pelelangan sehingga penawarannya dapat disesuaikan dengan masa berlakunya.Masa berlakunya minimal yang ditetapkan yaitu 1 tahun dan maksimal 2 tahun.
Hasil pelelangan tersebut akan dimasukan dalam kas desa dan dialokasikan untuk : pemerintah desa $20 \%$, pembangunan tempat-tempat ibadah, pembangunan saranasarana sosial, rehabilitasi hutan dan keperluan lainnya. Masa berlaku sasi dan jumlah penawarannya selama beberapa tahun terakhir dapat dilihat pada Tabel 4.

Tabel 4. Masa Berlaku Sasi Beserta Harga Penawarannya

\begin{tabular}{ccc}
\hline No & Masa Berlaku Sasi (Tahun) & Harga Penawaran (Rupiah) \\
\hline 1. & $2008-2010$ & 12.000 .000 \\
2. & $2010-2012$ & 13.500 .000 \\
3. & $2012-2014$ & 15.750 .000 \\
4. & $2014-2016$ & 17.000 .000 \\
5. & $2016-2018$ & 20.000 .000 \\
\hline
\end{tabular}

Sumber : Data Primer Setelah diolah, 2018

c. Hasil Hutan Yang Terkena Sasi

Hasil hutan yang terkena hukum sasi ditentukan berdasarkan kesepakatan masyarakat dalam acara pelelangan dengan pertimbangan hasil hutan tersebut tersedia dalam jumlah yang banyak dan mempunyai 
nilai ekonomis yang tinggi.Dari pelelangan terakhir ditetapkan bahwa hasil hutan yang terkena sasi adalah buah pala yang luasnya kurang lebih 30 ha, dengan potensi rata-rata $7.380 \mathrm{buah} / \mathrm{ha} / \mathrm{th}$. Hasil-hasil hutan tersebut dapat dilihat pada Gambar 8 .

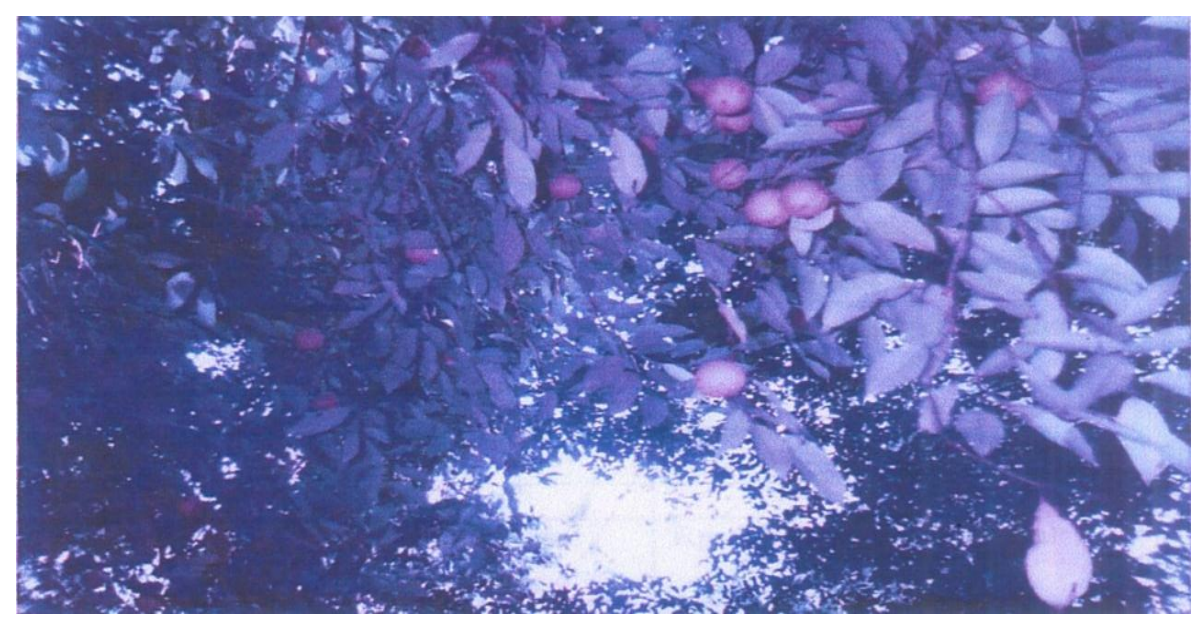

Gambar 8. Salah Satu Hutan Yang Terkena Hukum Sasi (Buah Pala)

a. Sanksi

Oleh karena itu berwujud larangan dan kebolehan, maka upaya menangkal terjadinya pelanggaran yang dilakukan dalam masa sasi atau pada saat tutup sasi menyebabkan pelakunya dikenakan sanksi.Sanksi dalam
Maluku, tetapi pada umumnya dikenakan sanksi berupa denda.Besarnya jumlah denda tergantung pada jenis dan banyaknya sumberdaya alam yang diambil (dicuri) oleh setiap warga masyarakat. Rincian mengenai sanksi dapat dilihat pada Tabel 5. hukum sasi berbeda-beda pada setiap negeri di

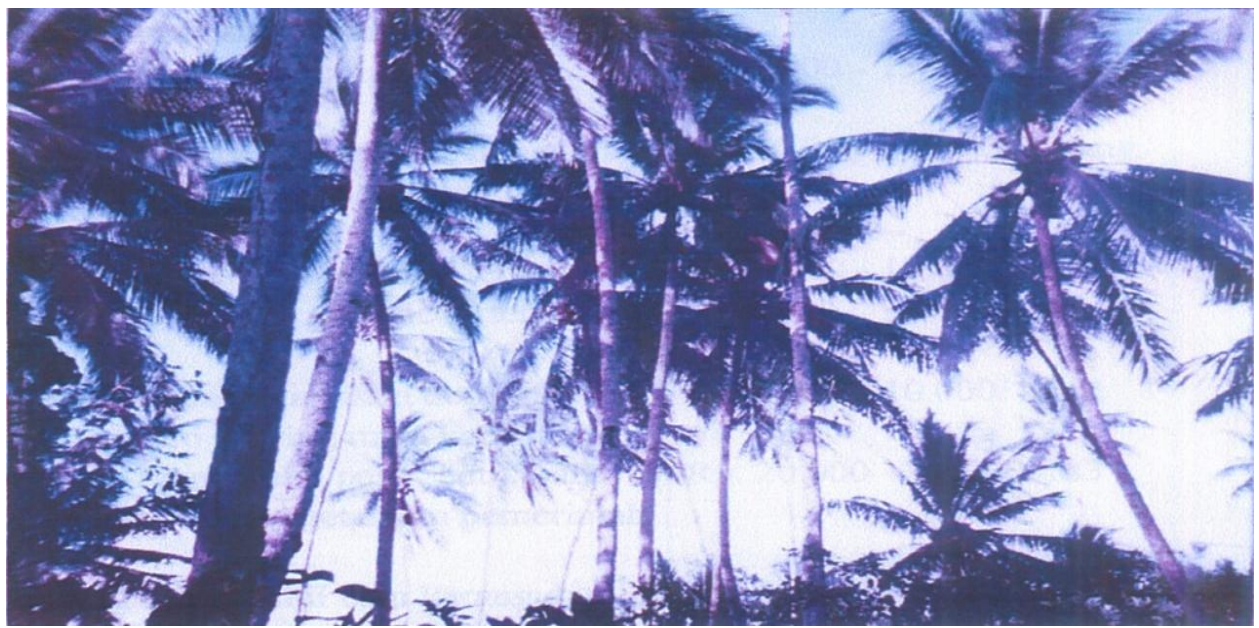

Gambar 9. Salah Satu Hutan yang Terkena Hukum Sasi (Buah Kelapa) 
Tabel 5.Peraturan-peraturan Sasi Beserta Sansksinya

\begin{tabular}{|c|c|c|}
\hline No & Aturan-aturan & Sanksi \\
\hline 1. & $\begin{array}{l}\text { Dilarang mengambil beberapa jenis sumberdaya alam } \\
\text { dihutan selama periode tertentu (Tutup sasi). } \\
\text { Dilarang mengambil sumberdaya alam (buah-buahan) }\end{array}$ & Rp. $7.500-10.000 /$ buah \\
\hline 2. & $\begin{array}{l}\text { yang masih muda. } \\
\text { Dilarang menebang pohon dihutan tanpa izin. }\end{array}$ & Rp. $5.000-7.500 /$ buah \\
\hline 3. & Dilarang menebang pohon disekitar sumber air dan & Rp. $50.000-300.000 /$ pohon \\
\hline 4. & $\begin{array}{l}\text { lereng gunung. } \\
\text { Dilarang menebang pohon-pohon bakau ditepi pantai. }\end{array}$ & Rp. $50.000-300.000 /$ pohon \\
\hline 5. & $\begin{array}{l}\text { Dilarang bagi bukan anak-anak negeri untuk masuk } \\
\text { kedaerah petuanan tanpa izin. }\end{array}$ & Rp. $5.000-150.000 /$ pohon \\
\hline 6. & $\begin{array}{l}\text { Dilarang mengambil lola dan teripang dipantai (laut) } \\
\text { selama periode tertentu (tutup sasi). }\end{array}$ & Rp. $10.000-15.000 /$ orang \\
\hline 7. & $\begin{array}{l}\text { Dilarang menangkap ikan dengan jaring karoro } \\
\text { (jarring mata kecil). }\end{array}$ & Rp. $7.500-10.000 /$ ekor \\
\hline 8. & $\begin{array}{l}\text { Dilarang mengambil pasir, batu, batu kerikil tanpa } \\
\text { sepengetahuan pemerintah negeri. }\end{array}$ & Rp. $1.000-10.000 /$ ekor \\
\hline 9. & $\begin{array}{l}\text { Dilarang mengambil batu karang diperairan pantai } \\
\text { tanpa sepengetahuan pemerintah negeri. }\end{array}$ & Rp. $20.000-50.000 / \mathrm{M}^{3}$ \\
\hline 10. & $\begin{array}{l}\text { Dilarang menangkap ikan dengan menggunakan } \\
\text { bahan beracun dan bahan peledak. }\end{array}$ & Rp. $30.000-50.000 / \mathrm{M}^{3}$ \\
\hline 11. & Dilarang mengambil telur burung maleo ditepi pantai. & Rp. $50.000-300.000 /$ sekali \\
\hline 13. & $\begin{array}{l}\text { Diwajibkan bagi seluruh warga masyarakat untuk } \\
\text { menanam kembali tanaman yang sudah mati. } \\
\text { Diwajibkan bagi seluruh warga masyarakat untuk } \\
\text { melindungi sumberdaya alam dan lingkungannya. }\end{array}$ & Rp. $5.000-7.500 /$ butir \\
\hline
\end{tabular}

Sumber : Data Primer Setelah di Olah, 2018

Selain sanksi berupa benda terdapat juga hukuman badan (cambuk) bagi anak-anak bahkan ada hukuman diarak mengelilingi desa dengan teriakan ejekan berupa pencuri dan lain sebagainya (jika diulangi sebanyak tiga kali).

Dari berbagai pelanggaran pelanggaran yang terjadi ternyata yang mempunyai intesitas yang tinggi adalah pelanggaran yang dilakukan oleh anak-anak seperti pengambilan buah pala yang masih muda dan menggugurkan bunga-bunga pala pada waktu bermain sehingga dikenakan sanksi berupa cambuk kepada mereka dan adanya hukuman tambahan dari orang tua mereka dengan harapan tindakan tersebut tidak diulangi lagi, hal ini dilakukan karena adanya 
rasa malu orang tua mereka dengan harapan tindakan tersebut tidak diulangi lagi, hal ini dilakukan karena adanya rasa malu orang tua kepada masyarakat terhadap tindakan anaknya.

Salah satu contoh kasus pencurian pernah terjadi pada tahun 1998, dimana pada waktu itu 3 (tiga) orang pemuda melakukan pencurian pala sebanyak 5 (lima) pohon pada

\section{Pelaksanaan}

Setelah kegiatan pelelangan selesai maka pengelola (kewang) mulai bekerja sesuai dengan apa yang diperintahkan oleh kepala kewang. Pekerjaan-pekerjaan tersebut dapat dideskripsikan sebagai berikut :

a. Pemasangan tanda sasi (Tutup sasi)

Sehari setelah kegiatan pelelangan usai, para anggota kewang akan berpencar diseluruh penjuru hutan, terutama ditempat-tempat yang banyak

dilalui orang untuk

pukul 19.00 WIT (malam hari), maka keesokan harinya anggota kewang mendapat laporan dari masyarakat dan pemilik pala sehingga ketiga orang tersebut dikenakan sanksi berupa denda sebesar Rp. 5.000 / buah dan hasil curiannya diambil oleh anggota kewang dan dikembalikan kepada si pemilik.

memasang/menancap tanda sasi, karena adanya tanda-tanda tersebut menandakan waktunya tutup sasi dimana semua masyarakat tidak bebas memasuki hutan untuk mengambil hasil hutan yang terkena sasi, namun untuk acara-acara tertentu seperti pernikahan, kematian dan lain-lain, masyarakat dapat diberi izin oleh lembaga kewang untuk mengambil hasil hutan sesuai dengan keperluannya. Salah satu tanda sasi dapat dilihat pada gambar dibawah ini

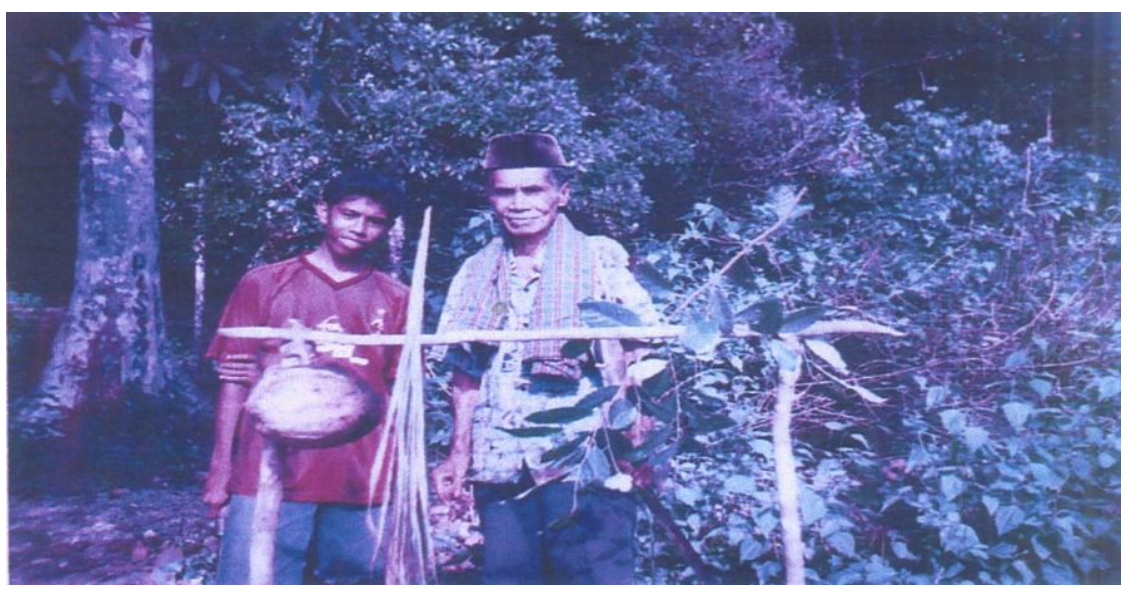

Gambar 10. Salah Satu Tanda Sasi Hutan (Marasabessy, 2018)

b. Pembuatan Pos Jaga

Selain tanda-tanda sasi, juga dibuat pos-pos jaga didaerah perbatasan antara wilayah hutan dengan daerah pemukiman. Hal ini dimaksudkan untuk selalu memantau sesame masyarakat yang keluar masuk hutan.
Pos-pos jaga tersebut biasa disebut dengan rumah kewang. 
c. Pemanenan (Buka sasi)

Setelah sekian lama anggota melakukan penjagaan terhadap hasil hutan yang terkena sasi dan masyarakat menahan diri untuk mengeksploitasinya, maka tiba saatnya kegiatan pemanenan (buka sasi) yang ditandai dengan pencabutan tanda-tanda sasi. Kegiatan ini dilakukan apabila hasil hutan sudah benarbenar masak atau layak dikonsumsi (dilakukan 4 bulan sekali) maka kewang akan mengumkan kepada seluruh masyarakat seisi negeri bahwa acara buka sasi akan dilaksanakan sampai selesainya kegiatan pemanenan melalui tabaos (pemberihan kepada masyarakat seisi negeri) .

Masyarakat akan berbondongbondong masuk hutan, tua-muda, pria-wanita, akan beramai-ramai dan bersam-sama melakukan eksploitasi terhadap hasil hutan yang dimilikinya, baik dimiliki secara pribadi maupun dimiliki secara bersama. Pada saat itu pula anggota kewang akan melakukan pengawasan terhadap mereka yang memanen guna mencegah terjadinya hal-hal yang tidak diinginkan, kondisi hutan pada saat itu sangat ramai.

Dari hasil pemanenan yang diperoleh, maka masyarakat diwajibkan untuk menyerahkan $10 \%$ dari hasil pemanenannya untuk pengelola (kewang) yang diserahkan pada pos-pos jaga yang telah dibuat. Hasil yang diserahkan pada pengelola kewang disebut suke .

Setelah kegiatan pemanenan selesai maka pihak pengelola (kewang) melakukan tabaos kepada masyarakat seisi negeri bahwa sasi akan ditutup, dan dilanjutkan dengan memasang tanda-tanda sasi serta perbaikan pos jaga. Kondisi diatas akan berulang terus menerus selama waktu yang telah ditentukan.

d. Pemeliharaan

Pemeliharaan terhadap semua sumberdaya alam yang ada dalam hutan dilakukan oleh pemegang hak (pemilik) baik pada wilayah petuanan milik perorangan (non ulayat) maupun wilayah petuanan milik bersama (hak ulayat) yang dilakukan pada saat tutup sasi.

Hal ini tidak terlepas dari peranan lembaga pengelola (kewang) dalam memberikan informasi dan masukan kepada pemilik untuk melaksanakan kegiatan pemeliharaan tersebut.

\section{3. pengawasan}

Kewang merupakan lembaga pengelola yang bertugas untuk melakukan pengawasan baik didalam hutan, pos-pos jaga maupun pemukiman terhadap semua sumberdaya yang ada dalam hutan selama jangka waktu yang telah ditetapkan pada pelelangan baik pada saat tutup sasi maupun pada saat buka sasi. Hal ini dimaksud untuk mencegah terjadinya pengrusakan dan pencurian terhadap semua sumberdaya hutan. Kegiatan pengawasan tersebut disebut maajaga. Hal ini dapat dilihat pada Gambar 4.

\section{Pengelolaan hasil}

Pengelolaan hasil hutan dimaksud adalah hasil yang diperoleh pengelola (kewang). Setelah kewang menerima 10\% dari hasil pemanenan masyarakat maka hasil 
tersebut akan dikumpulkan dirumah kepala kewang untuk dihitung dan diolah secara

bersama-sama. Hal ini dilakukan agar adanya transparansi antara kepala kewang dengan para anggotanya sehingga tidak ada saling mencurigai.

\section{Pemasaran}

Setelah semua hasil diperoleh sudah terkumpul dalam jumlah yang banyak maka kepala kewang akan memberikan para anggotanya untuk mengecek harga dipasaran, agar dapat menentukan langkah terbaik dalam pemasaran guna mendaptkan keuntungan yang maksimal. Pemasaran biasanya dilakukan dikota ambon atau langsung dibawa keluar ambon untuk dipasarkan.

\section{Hubungan antara Kelembagaan Sasi dengan Kebijakan Pemerintah}

\section{Kebijakan Pendukung}

a. Undang-undang nomor 41 tahun 1999 tentang kehutanan

Pasal 2 : Penyelenggaraan kehutanan berasaskan manfaat dan lestari, kerakyatan, keadilan, kebersamaan, keterbukaan, dan keterpaduan.

Pasal 3 : Penyelenggaraan kehutanan bertujuan untuk sebesar - besar kemakmuran rakyat yang berkeadilan dan berkelanjutan

Pasal 21 : Pengelolaan hutan meliputi kegiatan : tata hutan dan penyusunan rencana pengelolaan hutan, pemanfaatan hutan dan penggunaan kawasan hutan, rehabilitasi dan rekalamasi hutan, dan perlindungan hutan dan konservasi alam.

Pasal 60 : Pemerintah dan pemerintah daerah wajib melakukan pengawasan hutan, serta masayarakat atau perorangan berperan serta dalam pengawasan kawasan hutan.

Pasal 67 : Masyarakat hukum adat sepanjang menurut kenyataannya masih ada dan diakui keberadaannya berhak

a. Melakukan pemungutan hasil hutan untuk pemenuhan kebutuhan hidup sehari-hari masyarakat adat yang bersangkutan.

b. Melakukan kegiatan pengelolaan hutan berdasarkan hukum adat yang berlaku dan tidak bertentangan dengan undangundang

c. Mendapatkan pemeberdayaan dalam rangka meningkatkan kesejahteraannya.

b. Keputusan menteri kehutanan nomor 31 tahun $2001 \quad$ tentang penyelenggaraan hutan kemasyarakatan.

Pasal 3 : Penyelenggaraan hutan kemasyarakatan bertujuan untuk memeberdayakan masyarakat setempat dalam pengelolaan hutan, dengan tetap menjaga kelestarian fungsi hutan dan 
lingkungan hidup dalam rangka meningkatkan kesejahteraanya .

Pasal 4 : Ruang lingkup Penyelanggaraan hutan kemasayarakatan meliputi pengaturan tugas dan fungsi serta tanggungjawab pemerintah, pemerintah daerah, dan masyarakat dalam aspek-aspek penetapan wilayah pengelolaan, penyiapan mayarakat, perizinan, pengelolan , sampai dengan pengendalian.

Pasal 11 : penyiapan masyarakat merupakan upaya untuk meningkatkan kesiapan kelembagaan masyarakat setempat dalam pengelolaan hutan lemasyarakatan.

Pasal 31 : penyusunan rencana pengelolaan harus mempertimbangkan kepentingan publik dan lingkungan. Rencana pengelolaan disusun oleh pemegang izin secara partiipatif dengan melibatkan seluruh anggota kelompok dan difasilitasi oleh pemerintah kabupaten/kota.

2. Hubungan

Sasi merupakan suatu bentuk pengeolaan hutan yang dilaksanakan oleh lembaga pengelola (kewang) untuk meningkatkan pemanfaatan semua sumberdaya hutan secara lestari, kerakyatan dan keadilan, kebersamaan, keterbukaan dan keerpaduan guna meningkatkan kesejahteraan masyarakat. Hal ini dapat dilihat dengan adanya kesepakatan bersama oleh masyarakat dalam acara pelelangan untuk menetukan lokasi sasi, jenis-jenis sumberdaya yang terkena hukum sasi, memberi peluang yang sama kepada seluruh masyarakat, dan adanya kerjasama antara pengelolaan dengan masyarakat yang bertujuan untuk meningkatkan kesejahteraan masyarakat desa.

Fungsi - fungsi pengelolaan hutan secara umum seperti perencanaan, organisasi, peaksanaan dan pengawasan juga dtemukan dalam pengelolaan hutan dengan sistem sasi. Hal ini dapat dilihat dengan adanya perencanaan awal pengolaan untuk mennetukan wilayah berlakunya sasi, struktur organisasi pengelola (kewang) beserta tugas dan tanggung jawabnya, pelaksanaan sasi (Pemasangan tanda sasi, pemanenan dan pemeliharaan), pengawasan dalam pelaksanaan sasi, pengelolaan hasil yang diperoleh serta pemasarannya.

Sasi merupakan hukum adat atau adat kebiasaan yang dilakukan untuk memungut hasil hutan oleh masyarakat yang ada dipropinsi Maluku terutama propinsi Maluku tengah dengan cara-cara tertetntu. Dengan demikian sasi sebagai suatu bentuk kearifan lokal yang sangat dibutuhkan dalam pengelolaan hutan untuk memberdayakan masyarakat setempat dengan tetap menjaga kelestarian fungsi hutan dan lingkungan hidup guna meningkatkan kesejahteraan masyarakat.

Dari berbagai uraian diatas kita dapat melihat bahwa sebelum dikeluarkan kebijakan-kebijakan pemerintah dibidang kehutanan, terlebih dahulu masyarakat hukum 
adat daerah Maluku dengan keraifannya telah membuktikan kepada pemerintah bahwa substansi yang terkandung dalam kebijakan kebijakan tersebut sudah tercermin dalam perilaku kehidupan masyarakat sehari-hari yang dikenal dengan istilah sasi.

Selain itu sasi sebagai lembaga adat desa senantiasa bekerja sama dengan lembagalembaga formal lainnya guna meningkatkan pengetahuan dan kinerja dari pada lembaga sasi tersebut . lembaga-lembaga tersebut antara lain pemerintah desa, kecamatan, kabupaten dan istansi-istansi terkait seperti sub balai KSDA Maluku, sub dinas pertanian dan perkebunan, serta LSM. Kegiatan-kegiatan yang dilakukan adalah penyuluhanpenyuluhan dibidang kehutanan, pertanian dan perkebunan kepada masyarakat desa.

\section{Hambatan - hambatan}

Sasi sebagai model kearifan masyarakat Maluku dalam melestarikan sumberdaya alam dan lingkungan dalam pelaksanaannya mendapat berbagai hambatan.

Hambatan - hambatan tersebut diantaranya :

1. Kurangnya pengawasan dari pengelola (kewang) Karen luasnya petuanan negeri yang tidak sebanding dengan jumlah anggota kewang,

2. Adanya ketidaktahuan anak-anak terhadap ketentuan sasi yang mengakibatkan terjadinya banyak pelanggaran

3. Benturan antara hukum adat dengan hukum nasional, terutama pada saat berlakunya UU No. 5 tahun 1979 tentang pemerintah desa.

4. Adanya politik kehutanan dari pemerintah berupa pemberian izin HPH dan penetapan hutan lindung yang mengklaim wilayah petuanan negeri tanpa mengikutsertakan masyarakat.

Dengan adanya hambatan-hamabatan diatas maka keberadaan dari budaya sasi di Maluku sebagai kearifan masyarakat dalam pelaksanaannya mengalami berbagai hambatan bahkan dapat mengalami degradasi, maka dari itu upaya penanggulangannya harus dilakukan secara serius.

Di zaman reformasi sekarang ini terjadi perubahan pada semua aspek kehidupan masyarakat diantaranya keputusan pemerintah untuk mencabut izin beroperasinya HPH, pemberian kesempatan berusaha yang sebesarbesarnya kepada seluruh masyarakat daerah untuk melakukan pengelolan terhadap seluruh sumberdaya alam yang ada didaerahnya (otonomi daerah). Maka dari itulah pemerintah daerah (istansi kehutanan) harus melihat kondisi diatas sebagai suatu peluang dalam melakukan pengelolaan hutan dengan melibatkan semua pihak (Stakeholder) yang ada kaitannya dengan pengelolaan hutan tersebut.

Berkaitan dengan budaya sasi maka pemerintah daerah Maluku harus melihat kondisi-kondisi diatas sebaga hal penunjang untuk tetap mempertahankan kebudayaan budaya sasi. Salah satu langkah yang harus ditempuh oleh pemerintah daerah untuk tetap mempertahankan budaya sasi yaitu 
memasukan budaya sasi dalam peraturan daerah baik ditingkat provinsi, kabupaten, kecamatan, maupun desa sehingga budaya tersebut tetap eksis dan dilaksanakan oleh semua masyarakat dari generasi ke generasi di daerah seribu pulau tersebut. Selain itu kinerja dari lembaga pengelola (kewang) perlu

\section{Kesimpulan}

1. Sasi merupakan suatu bentuk larangan semantara kepada masyarakat untuk menahan diri dalam mengeksploitasi sumberdaya alam yang beradapada wilayah daratan, baik milik pribadi (non ulayat) maupun milik bersama (hak ulayat) dan wilayah lautan yang memiliki atau dikuasai oleh kepala desa. Dimanan semua yang bertugas untuk mengamnkan pelaksanaan semua kegiatan sasi, memberikan sanksi kepada para pelnggar, dan memeriksa batas-batas wilayah yang terkenasasi serta memasang tanda-tanda sasi.

2. Salah satu wilayah berlakunya hukum sasi yaitu wilayah darat (hutan) dimana dalam pengelolaan hutan mempunyai beberapa tahapan yaitu perencanaan, pelaksanaan (pemeliharaan, pemanenan, penanaman), pengawasan, pengelolaan hasil dan pemasaran.

\section{Saran}

1. Pemerintah diharapkan senantiasa memberikan dukungan dan mendorong pengembangan berbagai kebudayaan (kebiasaan) masyarakat yang ada Indonesia dalam kaitannya dengan pengelolaan hutan agar dapat dijadikan model pengelolaan hutan berbasiskan masyarakat. ditingkatkan dalam melakukan tugasnya, serta adanya peningkatan kesadaran masyarakat untuk tetap mempertahankan buadaya sasi dengan jalan memberikan arahan-arahan kepada setiap generasi untuk lebih mematuhi aturan-aturan yang terdapat dalam hukum sasi tersebut.

3. Hukum sasi merupakan bagian dari hukum adat yang diakui oleh pemerintah, maka sebagai kebijakan pemerintah yang diberlakukan seperti undang-undang No 41 tahun 1999 tentang kehutanan dan keputusan menetri kehutanan No.31 tahun 2001 tentang hutan kemasyarakatan dianggap masih sejalan.

4. Sasi sebagai suatu model kearifan lokal masyarakat Maluku dalam perkembangannya mendapatkan berbagai hambatan baik yang datang dari luar maupun dari dalam masyarakat, diantarany : kurangnya pengawasan karena tidak sebanding luas wilayah dengan jumlah anggota kewang, benturan antara hukum adat dengan hukum nasional serta kebijakan pemerintah berupa HPH yang merupakan ancaman terhadap wilayah petuanan negeri.

2. untuk tetap eksis dan mempunyai kekuatan hukum, pemerintah daerah perlu memasukan hukum sasi ini dalam peraturan daerah baik ditingkat provinsi, kabupaten, kecamatan maupun desa.

3. perlu adanya kerjasama antara instansiistansi terkait dengan pemerintah desa dalam pelaksanaan hukum sasi sehingga 
dapat dijadikan sebagai sistem pengawasan

dalam pengelolaan sumberdaya alam dan

\section{DAFTAR PUSTAKA}

Adonio tito, Ariton pudja, dan sindu galba, 1988. Penelitian dan pengkajian naskah-n2Saskah adat istiadat dikepulauan kei (peranan sasi dalam kehidupan masyarakat Maluku), Departemen pendidikan dan kebudayaan, Jakarta.

Departemen pendidikan dan kebudayaan, 1989. Kamus besar bahasa Indonesia. Balai pustaka, Jakarta

Dirjen kebudayaan, 1977. Monografi Daerah Maluku. Departemen Pendidikan dan kebudayaan, Jakarta

1989. Pengendalian social dibidang pelestarian lingkungan alam daerah Maluku. Departemen pendidikan dan kebudayaan, Jakarta

DPR RI,1999. Undang-undang Republik Indonesia N0. 41 tahun 1999 tentang kehutanan. Kopkar hutan, Jakarta7

Efendi, Z ,1986. Hukum adat ambon lease, Pradya paramita, Jakarta

Fakultas pertanian dan kehutanana UNHAS. 2000. Kumpulan modul pelatihan/penyegaran petugas, penyuluh, LSM, dan aparat praktek dalam rangka pembangunan pilot project hutan kemasyarakatan provinsi Sulawesi selatan (bantuan OECF), kerjsama fakultas pertanian dan kehutanan universitas hasanudin lingkungan.

dengan balai rehabilitasi lahan dan konservasi tanah jeneberang-walanae. Sulawesi selatan.

Kartasapoerta. G. A .1986. Klimatologi (pengaruh iklim terhadap tanah dan tanaman), bumu Aksara, Jakarta

Kissya. E.1993. Sasi aman haru-ukui (tradisi kelola sumberdaya alam lestari di Haruku). Yayasan sejati, Jakarta

Lokollo, J. E. 1994. Asas-asas hukum adat kelautan dan manfaatnya bagi pembinaan peraturan daerah kabupaten Maluku tengah dalam rangka implementasi undang-undang nomor 4 tahun 1982 dan undangundang nomor 1985. Hasil penelitian (tidak dipublikasikan) jurusan hukum pidana fakultas hukum universittas pattimura, Ambon.

Mailoa, Otje dan Nus sopamena, 1994. Adat dan upacara perkawinan daerah Maluku, departemen pendidikan dan kebudayaan, Jakarta.

Oherella. M. G. 1994. Hukum adat mengenai tanah air dan dipulau Ambon dan sumbangannya terhadap pembangunan hukum agrarian nasional (UUPA). Disertasi (tidak dipublikasikan) program pascasarjana universittas hassanudin, makasar. 
Poerwadarmita, 1982. Kamus umum bahasa Indonesia. Balai pustaka, Jakarta

Ruhulessin. H. 1990. Suatu studi tentang hukum sasi dalam pengelolaan sumberdaya alam diprovinsi Maluku (Kasus di Ambon dan lease). Tesis (tidak dipublikasikan) fakultas pascasarjana universitas hassanudin, makasar.

Zain. S. A 1995. Hukum lingkungan : kaidahkaidah pengelolaan hutan . PT. Raja Grafindo Persada. Jakarta.

1998. Kamus Kehutanan. PT.

Raja Grafindo Persada. Jakarta
Simon, Hasanu, 1993. Hukum jati dan kemakmurann: problematika dan strategi pemecahannya. Aditya media, Yogyakarta.

Sudarsono, Rahman Patji, Ratna indarwasih, Sdiyono, dan Saurmiati ali, 2000. Hak ulayat dikawasan timur Indonesia. Media Pressindo, Yogyakarta. 